\title{
LITERATURE REVIEW: GENDER AND RURAL DEVELOPMENT
}

\author{
*Surani Hasanati ${ }^{12}$, R Rijanta $^{1}$, AJ Pitoyo ${ }^{1}$ \\ ${ }^{1}$ Lecturer, Faculty of Geography - Universitas Gadjah Mada, Indonesia \\ ${ }^{2}$ Student, Doctoral Programe Faculty of Geography - Universitas Gadjah Mada, Indonesia \\ *Corresponding Author, Received: March 17, 2021. Revised: March 27, 2021. Accepted: May 26, 2021
}

\begin{abstract}
The purpose of this paper was to elaborate research of gender and rural development from geography perspective based on scientific research literature reviews. Four papers was selected to conduct this literature reviews. There are paper from Jennifer C. Langill, Chetan Choitani, Rosanna Quagliariello and friends, also Tamara Jacka and Sally Sargeson. These journals are interesting because it discusses the conception of empirical-scientific geography model as empirical science. Jennifer C. Langill's paper offered a conceptual framework for gendered division of labour and gendered livelihoods in rural Amazonia: highlighting how gender roles and gendered livelihoods in rural Amazonia: highlighting how gender roles and livelihood seasonality need to be understood as co-produced. Because gendered livelihoods are further complicated by household composition and life-stage, often over-burdened with productive and reproductive labour. While Chetan Choitani shows the impact of migration of men that include 'improved autonomy' and 'increased responsibility' for left-behind women, also provide conceptual pathways to understand migrationgender-food security linkages. Rosanna Quagliariello and friends offered solutions for gender mainstreaming in rural area by technocratic regulation, legality, implementation and law enforcement within the framework of gender mainstreaming that ensures the empowerment of women towards gender equality. While Tamara Jacka and Sally Sargeson Discover the highlight of local constructions of gender and representation.
\end{abstract}

Keywords: Gender, Rural Development, Gender and Development, Geography, Literature Review

\section{INTRODUCTION}

The village commonly is the smallest administrative unit in the development. Development planning at the village level is held by the village government by involving the community. The rapid development of economic activity in the rural area in recent years, allowing the development of the productive and social role of women with the rise of circular migrants. The widespread gender inequalities commonly became the characteristic of many rural societies in developing nations [1]. Find out the potential aspects to reduce gender inequalities in rural area commonly exist in many assets, inputs and services [2]. In ural areas development, gender mainstreaming encompasses all aspects of development [3]. Therefore, it is very necessary to study literature on how the development of gendersensitive coastal villages to realize sustainable livelihoods in the context of major changes due to rural development. The purpose of this paper was tried to elaborate research of gender and rural development from geography perspective based on scientific research literature reviews. Four papers was selected to conduct this literature reviews. There are paper from Jennifer C. Langill, Chetan
Choitani, Rosanna Quagliariello and friends, also Tamara Jacka and Sally Sargeson. These journals are interesting because it discusses the conception of empirical-scientific geography model as empirical science.

\section{METHOD}

This paper made by literature review method using systematic review. qualitative approach in systematic review is used to synthesize (summarize) the results of research that is qualitative descriptive. Synthesis method (summarizes) the results of this qualitative study was called meta-synthesis. By definition, metasynthesis was a technique of integrating data to obtain new theories or concepts or a deeper and more thorough level of understanding [4].

\section{RESULTS AND DISCUSSION}

[5] The co-production of gendered livelihoods and seasonal livelihoods in the floodplains of the Peruvian Amazon, Gender, Place \& Culture, DOI: 10.1080/0966369X. 2020.1781796 
By the time she wrote a paper was a graduate student of Geography Department, McGill University, Montreal, Canada. Her study literature finding was emphasizes the fact that gender-based analysis is a forever study. It needs to be ongoing and iterative given that gender roles and identities are constantly being (re)negotiated.

She note on ethnographic observation and analysis in two riverine villages located on the floodplains of the Ucayali River, Peru. Her research focus collected primarily about "women in spaces". She used participant observation and informal conversations. She targetted livelihoods, gender, and household division of labour. Furthermore, she addressed conceptual framework of both gendered livelihoods and seasonal livelihoods to question the relationship between gender and seasonality in riverine Peruvian Amazonia.

To answer her research question, she cut a pie slices into four subthemes: First, Household division of labour. In this finding and discussion, she was not only figure out the household size and composition shapes household division of labour, but also argue that male-dominated activities are collecting firewood and income-generating activities other than agro-fishing. Other incamegenerating activity was in transportation sector using a boat for cash income. She find out "women's space" as domestic tasks. These tasks belongs to female-dominated activities.

Second, Flood season: livelihoods focused within the household. She shows that during the flood season, whole families keep stay in their houses. They also copes strategies and life-ways against flood such as discontinue for a while from agriculture, using transportation facility they had such as canoes and boats to get around, also they did seasonal activity during flood that was fishing. While men are gone, women are usually at home during the day to take care of the children and childcare and manage the household. Mostly happened in society that men was fishing and women the one who sold it. Women usually take young children with them to the market. Thereby, she argues that women are simultaneously undertaking childcare and economic responsibilities.

Third, Flood recession: livelihoods focused outside the household. She described that during the flood recession period, most livelihood activities are back to agriculturally-based. She found seasonal labour migration is relatively common during the flood recession, exclusively amongst men. Men who migrate during seasonal labour work are often gone for some periods, weeks or months at a time, and during this time their wives act as 'de facto' household heads while also take a part as labour for the agricultural fields. Social life was flourishes during the flood recession. There are several bigger social events during the flood recession season, many of which are shared with other villages in the region. She states there is direct contrast to the flood season, livelihoods and life-ways are focused outside of the household during the flood recession. Most tasks remain gendered, however at a larger scale with men and women each working and socializing with those outside the household.

Fourth, Seasonality gendered, gendered roles seasonal: wider implications. At the end of her result and discussion phase, she emphasis four important broader implications findings: 1) Women are more involved in the market and spend more time in the home. 2) Seasonal migration mostly occurs during the flood recession creating significant impacts for gendered livelihoods and gendered division of labour, as women are further burdened in livelihood responsibilities when their husbands seasonally migrate. 3) The concept of women's triple burden of labour by Moser that women bear nearly all responsibilities for household reproduction and care. 4) Gendered livelihoods in her study area conceptualized as dynamic and temporal.

She conclude that seasonal and gendered livelihoods shape the public and private spheres. It was relate with livelihoods coped by flood. Her conclution is similar with [6] that gender roles and livelihood seasonality co-produce each other.

[7] Gendered livelihoods: migrating men, leftbehind women and household food security in India, Gender, Place \& Culture, 27:10, 13731394, DOI: 10.1080/0966369X.2019.1681366

He is an Assistant Professor in Inequality and Human Development Programme of School of Social Sciences, National Institute of Advanced Studies (NIAS), India. His paper aim was to highlight interconnections between migration, women left behind and household food security; To assesses the food security implications of the outmigration of men for rural households headed by women.

He argues the need to address socioeconomic mechanisms underpinning gender-based vulnerabilities to food security. There is limited research when women assume household headship. It was highlighted that explicitly looks at the interconnections among migration, gender and food security. His research was conducted using a case 
study approach that involves field research in Siwan district of the eastern Indian state of Bihar, where the out-migration of men is high. The data used was mixed methods, including surveys, observations and qualitative interviews.

His reseach result draws that in many families, women acted as the de facto household heads in the absence of men. He found that the degree of participation of women within the household varied by the type of familial arrangement. He generated also that women in nuclear households enjoyed greater autonomy and decision-making. Another finding was that migration of men did not usher in absolute freedom for women, but seemed to enhance the role of women within and outside the household and contributed to their improved agency, at least for the time that the men were absent. There were significant of hardships for most rural women especially from poor households that caused by the migration of men. He also found two interlinked factors through which gender of the household head mediates food security outcomes. His findings show that the more marginalized having more experience the intersectional effects migration, gender relations and food insecurity.

He highlighted that the gender based disadvantage in food security outcomes faced by household headed regarding autonomy, as what mentioned by [8] women have the internal power to control life and the ability to gain access to everything. He also conclude that while women's enhanced autonomy, decision-making power and resource access are found to improve household welfare outcomes.

[9] Achieving Gender Equality and Sustainable Rural Development in The Mediteranean: Institutional Obstacles and Possible Solutions, Agriculture \& Forestry, Vol. 61 Issue 1: 261 271, 2015, DOI: 10.17707/AgricultForest. 61.1 .33

The corresponding author is Rosanna Quagliariello. She is a Professor focus on gender topic in Mediterranean Agronomic Institute, Bari, Italy. Her paper and team aim to analyze institutional barriers and possible solutions can be implemented in achieving gender equality and sustainable rural development in the Mediterranean based on Millenium Development Goals (MDGs).

Rosanna Quagliariello et all describe that While gender equality has progressed over the past 25 years, the reality remains that there is still a gap between the expectations of equality and the reality of everyday life for women in the Mediterranean. Technically and politically, it can be recognized that the empowerment of women in rural areas is a prerequisite for global food security and sustainable development. There are institutional barriers affecting progress in achieving gender equality in developing countries associated with local political, cultural and socioeconomic conditions. They argue to identify institutional barriers and why they need to be addressed, but identifying solutions is much more important. Gender should be everyone's concern, but gender also requires people to remove gener mainstreaming's barriers, and fight for in addition to understanding well the meaning of the concept of gender as well as how to integrate it into programs and policies.

What they conclude is same conclution from [10] that gender should be everyone's concern who understand both what the concept of gender means and how to integrate it into rural development.

[11] Representing Women in Chinese Village Self-Government: A New Perspective on Gender, Representation, and Democracy, Critical Asian Studies, 47:4, 477-494, DOI: 10.1080/14672715.2015.1079990

Tamara Jacka is the corresponding author. Tamara is a Professor in Department of Political \& Social Change, Australian National University. While Sally is Faculty Member of ANU College of Asia and the Pacific. Her paper was about to analyze women's substantive representation, democracy, and gender equality.

Regarding deliberative and feminist theories of substantive representation, she initially assumed that women's substantive representation, democracy and gender equality are mutually constituted. Her publication shows that village selfgovernment could make a much-needed contribution to the achievement of all three. She foud that commonly people interested in the potential for the substantive representation of women to contribute to a reduction in gender inequalities in village life. She address it as important finding because Chinese rural women as a group are disadvantaged relative to men, especially with regard to incomes, access to key resources such as land, and political participation.

She and her team draws on qualitative fieldwork research in villages in Zhejiang. It is a wealthy coastal province and Yunnan but also became a poorer province in China's southwest. She selected the village to reflect a range of different political economies, incomes, and rates of women's proportionate representation in village government. 
Her research finding shown in three aspects. First, locating their study in relation to theorizations of democracy, gender, and substantive representation. Constituencies interactively constitute representatives' roles. According to her, although it was illuminating to examine the political claims of members of village government, it was even more useful to compare these with the constructions of representatives' roles and work evident in the claims of ordinary villagers. Second, the political economy and self-government institutions in they field sites. While the leaders of all four Yunnan villages claimed that hamlets each elect villager representatives, in practice, representatives are commonly appointed by village leaders. In fact she founf that Most male representatives are hamlet heads and deputy heads, and most female representatives are family planning assistants.

Third, fieldwork findings about local social constructions of governing. She found many peope claimed that there is a ned for women in village government. But it has hidden varying reasons. Women and men have different strengths and weaknesses. She addressed gender divisions of labor also were said to require women's participation in village government. She found that in Yunan still has belief that "men rule outside, women rule inside" especially in the social construction of governing roles. They stated that factors shaping villagers'interests was gender inequalities or gender divisions of labour.

They show that gender equality is not a prerequisite for substantive representation of women. This is true even if we limit considerations for gender parity in political participation, which is not on our field site. Substantive representation of women contributes to democracy by expanding the reach of people who are able to shape collective decision-making, and the various interests and needs considered in the collective decision-making process.

Their study shows that substantive representation of women can be achieved even in authoritarian circumstances, by weak democratic sub-national governments that include few women. In such an environment, it is very important because it enhances democracy. However, in addition to increasing women's contribution to collective decisions, not least that reduces gender inequality. More research is needed to determine how and under what conditions substantive representation of women improves gender equality.

\section{CONCLUSION}

Jennifer C. Langill's paper offered a conceptual framework for gendered division of labour and gendered livelihoods in rural Amazonia: highlighting how gender roles and livelihood seasonality need to be understood as co-produced. Because gendered livelihoods are further complicated by household composition and lifestage, often over-burdened with productive and reproductive labour. While Chetan Choitani shows the impact of migration of men that include 'improved autonomy' and 'increased responsibility' for left-behind women, also provide conceptual pathways to understand migrationgender-food security linkages.

Rosanna Quagliariello and friends offered solutions for gender mainstreaming in rural area by technocratic regulation, legality, implementation and law enforcement within the framework of gender mainstreaming that ensures the empowerment of women towards gender equality. While Tamara Jacka and Sally Sargeson Discover the highlight of local constructions of gender and representation. Among them, can be concluded that gender in rural development still seen as standalone actors in the process of village development.

\section{ACKNOWLEDGEMENTS}

The author is grateful to Dhia Fauzia Rahman and Dian Eky Pratiwi for their help as assistants with literature collections.

\section{Disclosure statement}

In accordance with Journal SJDGGE policy and my ethical obligation as a researcher, I am reporting that I do not have any financial or business interests in publishing this research. This research is purely an academic exercise. I carried out this literature reviews as part of my doctoral thesis requirements at the Faculty of Geography, Universitas Gadjah Mada. This literature review work were partially funded by Grant 2020 Faculty of Geography Universitas Gadjah Mada. Thus, I have disclosed the funding sources for this work, and there are no conflicts that could potentially arise from this paper.

\section{REFERENCES}

[1] Hadi, A. International Migration and The Change of Women's Position Among the Left Behind in Rural Bangladesh, Population, Space and Place 7:1 53-61, DOI: 10.1002/ijpg.211. 2001

[2] UNDP. Africa Human Development Report 2012. Towards a Food Secure Futue. United Nations Development Programme. 2012 
[3] IFAD. Gender Equality and Women's Empowerment, Policy, International Fund for Agricultural Development. 2012

[4] Perry, A. \& Hammond, N. Systematic Review: The Experience of a PhD Student, Psychology Learning and Teaching, 2(1), 32-35. 2002

[5] Jennifer C. Langill. The co-production of gendered livelihoods and seasonal livelihoods in the floodplains of the Peruvian Amazon, Gender, Place \& Culture, DOI: 10.1080/0966369X.2020.1781796. 2002

[6] Dzuhayatin, Siti Ruhaini. Rezim Gender Muhammadiyah: Kontestasi Gender, Identitas dan Eksistensi, Yogyakarta: ustaka Pelajar. 2015

[7] Chetan Choithani. Gendered livelihoods: migrating men, left-behind women and household food security in India, Gender, Place \& Culture, 27:10, 1373-1394, DOI: 10.1080/0966369X.2019.1681366. 2020

[8] Fakih, Mansour. Analisis Gender dan Transformasi Sosial, Yogyakarta: Pustaka Pelajar. 2013

[9] Rosanna Quagliariello, Atef Hamdy, Giuliana Trisorio Liuzzi \& Chiara Ciannamea. Achieving Gender Equality and Sustainable Rural Development in The Mediteranean: Institutional Obstacles and Possible Solutions, Agriculture \& Forestry, Vol. 61 Issue 1: 261 271, 2015, DOI: 10.17707/AgricultForest. 61.1.33. 2015

[10] Abdullah, Irwan. Sankan Paran Gender, Yogyakarta: Pustaka Pelajar. 2006

[11] Tamara Jacka \& Sally Sargeson. Representing Women in Chinese Village Self-Government: A New Perspective on Gender, Representation, and Democracy, Critical Asian Studies, 47:4, 477-494, DOI: $10.1080 / 14672715.2015$. 1079990. 2015 